\title{
EFFECT OF FATTY ACIDS ON THE RESPONSE OF THE LIVER MICROSOMAL BIOTRANSFORMING ENZYMES IN THE NILE TILAPIA OREOCHRO.WIS NILOTICUS EXPOSED TO QUINTOZENE
}

\author{
Shchata E. Elowa \\ Department of Zoology'. Faculty of Science. Helwan University. Egypt
}

Key Words: Cytochrome P-450. Cytochrome bs. EROD. ECOD. UDPGT . GST. Polyunsaturated fatty acids (PUDFAS). microsomes, cytosol. Oreochromis niloricus

\section{ABSTRACT}

$\mathrm{T}$ his study was conducted to investigate the impact of nutritional environmental factors on the efficacy of microsomal tiotransforming enzymes to organic xenophobic in the freshwater fish $O$. niloticu exposed to the pesticide quintozene. Two groups of fish, one was maintained on a normal diet (A) and the other on a diet supp!emented with fish liver oil (B) for 4 weeks. Then the fishes were treated with quintozene by interperitonial injection of $150 \mu l(30$ $\mathrm{mg} / \mathrm{kg}$ of body weight) and the responses of liver microsomal biotransforming enzymes were assessed after 48 hours.

Treatment with quintozene of fishes maintained on diet $B$. produced an increase in microsomal contents of cytochrome P-450 and cytochrome $b_{5}$ reaching 1.44 and 2.88 fold respectively compared with group $\mathrm{A}$, whereas. activities of 7-ethoxyresorufin - $\mathrm{O}$ - deethylase (EROD) and 7- ethoxycoumarin- deethlase (ECOD) reached 2.8 to 5.11 fold respectively.

Similarly, the phase II enzymes, Uridine diphosphoglucuronyl - transferase (UDPGT) activity was less induced in fishes fed diet A than diet B: whereas an increase of 1.64 and 4.7 fold respectively were noticed. Cytosolic glutathione- S- transferase (GST) was not affected by either treatments.

In addition, a fish liver oil rich dietary supply of polyunsaturated fatty acids (PUFAs) may prevent these changes, even in a long- term subchronic exposure.

The results indicated that fatty acid composition of diet of Oreochromis niloticus can affect significantly the biotransforming enzymes in response to xenobiotic pollutants. 


\section{INTRODUCTION}

Environmental parameters such as temperature and nutrition can play an important role in the ability of organisms to respond to toxic chemicals, particularly in the aquatic environment (Jimenez ef al., 1988; Jimenez and Burtis; 1989; Storr el al. ,1995; Boon et al., 1997 ; Kakela et al., 2001)

It is well established that fish have the ability to metabolize foreign compounds in a similar manner to that of mammalian species (Adamson, 1967). In mammals, numerous dietary factors are known to influence hepatic systems including pliase 1 oxidative enzyme such as cytochrome P-450, dependent monooxygenase system and phase II conjugating enzymes.

Although, the role of these enzym:s is primarily detoxification and metabolic activation, cytochrome P-450 can convert xenobiotic compounds to highly reactive and potentially carcinogenic forms (Wolf, 1986 ; Yuan et al.. 2001).

The mixed function oxidase (MFO) system plays a determinant role in the initial stage of detoxification of xenobiotic lipophilic compounds. One of the basic features of this system is its substrate inducibility which stimulates thes synthesis of new functional proteins (Payne et al., 1987; De Matteis, 1988 ; Wong er al. 2001).

Ankley and Blazer (1988) reported that diet can affect the toxicity of xenobiotics to fish through alterations in hepatic enzyme systems.Jimenez ef al., (1988) and Audw \& Wurs (2001) have studied the effects of different commercial diets on the response of hepatic ERCD and hepatocytological changes of EROD activity in an immature demersal fish and blue gill sunfish exposed to Benzo (a) Pyrene. Dietary modification by starvation (Andersson et al., 1985: Jimenez ef al., 1987 and Jimenez : Burtis. 1989), or different protein levels in diet that are known to affect the enzymatic system and monooxygenase activities in some fish species (Stott and Sinnhuber. 1978).

El Wald. (1999) reported that chlorinated fatty acids do not induce cytochrome P-450 and EROD in fish. This lack of organisn? recognition of chlorinated fatty acids as xenobiotic compound gives a new perspective on the risk assessment of these compounds.

Ankley and Blazer (1988) reported that. from a toxicological point of view: it was important to determine whether relatively minor differences in commercial diets affected renobiotic metabolism in fish. High cyclopropenoid fatty acid levels in diel affected hepatic 
monooxygenase activities in rainbow trout Sulmo gairdner: (Elisle el al. 1978: 1983 and Kakela et al. 200l) while vitamin C deficiency was reported as being involved in lower hepatic monooxygenase activities in channel cat fish Ictalurus punctatus. (Ankley and Blazer. 1988).

Ankley et al. (1989) have shown that the type of lipid extracted from fishes added to the diet can affect basal biotransformation activities as a tool in biomonitoring.

Fishes are likely to face important diet change in relation to seasonal variations of available food. Therefore, there is relatively little information concerning effects of dietary lipid on response of biotransformation activities of pesticides in exposed fishes.

The present study aimed to investigate the response of liver monooxygenase (cytochrome $\mathrm{P}-450$ and cytochrome $b_{s_{-}}$contents and the activities of (EROD); (ECOD) and (UDPGT) and (GST) activity phase II enzymes to quintozene exposure in two groups of $\boldsymbol{O}$. niloticus, one was fed a normal commercial diet and the other was maintained on another diet supplemerited with fish liver oil.

\section{MATERIALS AND METHODS}

Quintozene pesticide Pentachloronitrobenzene (PCNB) (98\%) an aromatic hydrocarbon derivative, used in this study was supplied as technical grade from Help Pesticides and Chemical Company, Free Zone, New Damietta, Egypt.

Fish oil, nicotinamide adenine dinucleotide phosphate oxidized (NADP); reduced NADPH; substrates were purchased from Sigma Chemicals Company. All other chemicals were of the highest available commercial grade.

Fishes

Nile tilapia (Oreochromis niloticus) weighing $50 \pm 5 \mathrm{~g}$ were obtained from El-Abassa fish farm and transported to a large water Aquarium $(70 \times 50 \times 40 \mathrm{~cm})$. Fishes were acclimated to laboratory conditions for 4 weeks before experimentation. The fish were randomized in well aerated dechlorinated tap water in the aquarium with dissolved oxygen (6-8) $\mathrm{mg} / \mathrm{l} ; \mathrm{pH}$ (7.4-7.7); temperature $24 \pm$ $1^{\circ} \mathrm{C}$; total hardness $80 \mathrm{mg} / \mathrm{l}$ as $\mathrm{CaCO}_{3}$. Analysis was carried out according to APHA (1998). 


\section{Experiment 1:}

In this experiment, fishes were divided into two groups; 100 individuals each. The fish of the first group were fed on commercial $\operatorname{diet}(\operatorname{diet} \mathrm{A}$ ) that contained total protein $45 \%$; cereal $20 \%$ : total fat $12 \%$ and fish liver oil $0 \%$, while the second group was fed on the same commercial diet but supplemented with $11 \%$ fish liver oil (diet B).

Twenty five fish of each group received a single intraperitonial injection of quintozene $(150 \mu 1,30 \mathrm{mg} / \mathrm{kg}$ of the body weight) toluene.The remaining twenty five fish of each group received an injection of sterile toluene and served as control.

After treatment with quintozene fishes were placed in separate aquaria. Then they were sacrificed $48 \mathrm{hr}$ from the beginning of treatment. This period was established from a preliminary experiment as given a marked response of the monooxygenase activities (Lemaire, 1990 ; Lemaire et al., 1990 a.).

\section{Microsomal isolation:}

Fresh excised liver was rinsed in $150 \mathrm{mM} \mathrm{KCl}$ solution. following the procedures reported by Ariyoshi et al. (1970) and Arizono el al. (1982).

The minced livers were homogenized in 4 volume of $250 \mathrm{mM}$ sucrose, $10 \mathrm{mM}$ HEPES buffer ( $\mathrm{pH}$ 7.4) with a Potter - Elvehjem glass and a Teflon homogenizer. The homogenates were centrifuged at $12,000 \mathrm{~g}$ for $15 \mathrm{~min}$ in Beckman. $\mathrm{J}_{2}-\mathrm{Hs}$ centrifuge. The supernatants were recentrifuged at $105.000 \mathrm{~g}$ for $60 \mathrm{~min}$ in a Beckman TL, 100 Ultracentrifuge.

Microsomal pellets were resuspended in $2.5 \mathrm{ml}$ of $250 \mathrm{mM}$ sucrose; $10 \mathrm{mM}$ Hopes buffer (pH 7.4) containing $20 \%$ glycerol and the supernatant with a cytosol fraction. Microsomal suspension were frozen and stored in liquid nitrogen till analysis.

Assays:

Cytochrome P-450 and cytochrome $b_{5}$ contents. NADPH cytochrome $C$ reductase and Uridine diphosphoglurony! transferase (UDPGT) activity were determined in the microsomal fraction. Glutathione $-S$ - transferase (GST) activity in cytosol. Cylochrome P-450 cytochrome $b_{5}$ were assayed after reduction by sodium dithionite according to Stegeman el al. (1987): NADPH Cytochrome $C$ reductase as described by Masters ef al. (1967): 7 ethoxyresorufin - O - deethylase (EROD) according to Klotz et al. (1984). 7 - ethoxy coumarin -O - dealkylase (ECOD) as described by Ullrich and Weber (1972): GST activity as described by Hebig ef 
al. (1974) with 1 - chloro - 2. t- dinitrobenzene (CDNB) as substrate and UDPGT as described by Frei (1970). Microsomal and cytosolic protein concentrations were determined according to Lowry et al. (1951). Enzyme activities were measured by using LV: Visible Spectrophotometer Perkin - Elmer model Lambda; (Cytochrome P. 450: Cythochrome $b_{\xi}$ NADPH - cytochrome $C$ reductase: GST and UDGT). on Jenway 6200 Spectrofluorimeter (EROD and ECOD). All enzymatic assays were demonstrated to be linear for time and protein concentrations used in experiments.

\section{Diet composition:}

Analysis of the diet using the method reported by lemaire et al. (1991 b), the two diets differed mainly with respect to fish liver oil ( $0 \%$ level in diet $A$ and $11 \%$ in $\operatorname{diet} B$ ). Fish oil contained essential fatty acids. fatty acid composition was analyzed according to Flock et al. (1957), Diet B contained 26\% docosahexanoic acid and $54 \%$ linolinic acid, whereas no trace of these polyunsaturated fatty acids (PUFA),could be detected in $\operatorname{diet}$ A. as (Table 1).

Statistical analy'sis:

Statistical analysis of results was performed by student t-test (Sokal and Rohif, 1981).

\section{RESULTS AND DISCUSSION}

Treatment with quintozene did not increase cytochrome $P$ 450 level, cytochrome $b_{j}$ and NADPH-cytochrome $c$ reductase activity in fishes fed diet A (Fig.1). In contrast, with diet B. cytochrome P-450, cytochrome $b_{5}$ and NADPH-Cytochrome C reductase were increased respectively by 1 and $1.44,1.48$ and 2.8 and 1 and 1 fold in diet $B$ respectively, as a consequence of this difference (Table 2)

Quintozene treated fish fed the commercial diet $\mathrm{B}$ had higher level of cytochrome P-450 than cytochrome $b_{5}$ and NADPHcytochrome $C$ reductase fed diet A. (Figs. $1 \mathrm{a}, \mathrm{b}, \mathrm{c}$ )

The contents of cytochrome P-450, cytochrome $b_{5}$ and NADPH cytochrome $C$ were slightly increased in diet $A$ but the activity increased in diet B. In mammals Cytochrome P-450 has multiple forms which differ with respect to substrate specificity and degree of infusibility by drugs and other chemical (Ryan et al.. 1975 ; Haugen et al., 1975). 
Numerous studies have shown that dietary lipid markedly affects xenobiotic metabolism in mammals (Wade et al., 1985). In fish, the information is more limited with respect to conjugating ability of enzymes in fish treated with pollutants, but the effect of nutrition and lipid composition on xenobiotic metabolism have been demonstrated (Ankley and Blazer 1988; Jimenez et al., 1988; Ankley et al., 1989).

Both categories of Congeners are probably metabolized by different families of cytochrome P-450 (1A and 2B), the levels of which apparently differed with the species of cat fish and the induction of cytochrome P-450 enzymes offers the most likely explanation for this phenomenon, but starvation could have a similar effect on occasion, (Boon ef al., 1997). It was shown that the main constituents of fish oil are the polyunsaturated fatty acid (PUFA) linolenic and docosahexaenoic acid (Lemaire et al., 1991b). Sarasquete and Segner (2000) have shown that cytochrome P-450 monooxygenase has an important function in the biotransformation of many xenobiotics including polynuclear aromatic hydrocarbons (PAH), and planer organochlorine compounds. The metabolism of $\mathrm{PAH}$ can lead to detoxification or production of reactive intermediates. In fish. docosahexaenoic acid is an essential fatty acid either absorbed during digestion or synthesized from linolenic acid. Fatty acids undergo bioconversion by elongation and desaturation by desaturase. Ariyohi ef al. (1970). sated that the capacity to elongate and desaturate linolelic acid varies with the species, but desaturation activity is much greater in freshwater fish (Dwen el al.. 1975) than in marine fish (Cowey et al., 1976. Fuji et al., 1976 ; Tinoco. 1982).

Lack of polyunsaturated fatty acid (PUFA) elicits numerous hepatic pathological damages (Mosconi, 1987). This lack of the organism for recognition of chlorinated fatty acid as xenobiotic compound gives a new perspective on the risk assessment of these compounds (El Wald. 1999). Stegman ef al. (1997) have shown that the total cytochrome $\mathrm{P}-450$ contents of 7 species of fishes varies between 0.1 and $0.5 \mathrm{n} \mathrm{mol} / \mathrm{mg}$ protein and cytochrome $b_{5}$ content. between 0.025 and $0.25 \mathrm{n} \mathrm{mol} / \mathrm{mg}$ protein. In contrast to these 7 species. fishes had microsomal P.450 contents near $1.7 \mathrm{n} \mathrm{mol} / \mathrm{mg}$. among the highest value as reported in untreated fishes. Fishes fed $\operatorname{diet}$ A show'ed lower activity of phase I and phase II enzymes than those fed the diel B supplemented with fish liver oil. No differences were observed in cytochrome P-450. cytochrome $b_{5}$ and NADPH cylochrome $C$ reductase compared with the control level in fish fed with either one of the lwo different diets. However. higher induction 
response was observed in diet B than in diet A. Kakela et wl. (2001) reported that. in the minks fed fish - based diets and exposed to Aroclor 1242. the different changes in the microsomal fatty acids minks fed a diet rich in fat and low in polyunsaturated fatty acids (PUFA), the PCB increased the percentage of oleic acid (18- In-9. characteristic of the storage TGS) at the expense of $n-;$ PUFAS. In contrast to some changes in cytochrome. P-450 content (Nave and Engalhaedt. 1982: Stegman, 1987). cytochrome $b_{5}$ has rarely been observed in these studies in fish. Although the role of cytochrome P450 and cytochrome $b_{5}$ in pesticides has not yet been defined in fish. it is possible that as in mammals it may increase the overall efficiency of electron transport to cytochrome P-450 (De- Marco and Mccoy. 1985) . Treatment with quintozene increased microsomal UDPGT activity by 1.64 and 4.68 fold in fishes fed with diet A and B respectively, (Fig. 2 and Table 2). In contrast, cytosolic glutathione $\mathrm{S}-$ transferase activity was not affected in fishes fed diet $\mathrm{A}$, whereas. it was significant by $57.33 \%$ in fishes fed diet B.

UDPGT activity was similarly more induced in quintozene treated fish fed with polyunsaturated fatty acid (PUFA) contained in diet $B$. This result is in agreement with those data reported by (Ankley et al., 1986 and Ankley and Blazer 1988).

Gadabui and Goksoys (1996) observed in Tilapia fish and Mud fish exposed to the aromatic chlorinated hydrocarbon, elevated levels of EROD, UDPGT and GST activities.In contrast. cytosolic GST activity in O.niloticus showed $57.33 \%$ inhibition after quintozene treatment in diet (B). Conversely, in channel cat fish, GST activity toward CDNB shows higher level with a diet containing numerous n-3 series fatty acids (Garcia et al.. 2000 ; kakela et al., 2001). Koss et al. (1991) have observed also the activities in phase II enzymes are known to be weak in fish and greatly varied according to the used substrate. However. CDNB appeared to be good substrate for GST activity with least specific difference (Gregus et al., 1983). The results indicate that diet can significantly affect the enzymatic metabolism and thereby the toxicity potential of organic pollutants in O.niloticus and other fish fed a diet containing essential fatty acids could be more sensitive to xenobiotic enzyme induction than those lacking polyunsaturated fatty acid in diet. Liver microsomal EROD activity followed the same qualitative pattern with respect to quintozene treatment and diet. However, the responses were more marked for fish fed diet (B), 2.8 compared with 1.9 fold for diet $A$ 
respectively, (Fig. 3 and Table 2). Concerning ECOD activity, a slight difference was observed with diet $A$ between the control and quintozene treated fish. whereas, higher level appeared in quintozene treated fish with diet B compared to control (4.42 and 5.11 fold, respectively. The induction effect of quintozene on liver microsomal EROD activity were quite similar in groups with diet (A). but the induction for diet $B$ was higher in polyunsaturated fatty acid. Similarly, ECOD activity was slightly induced only in diet (B), but greater induction was observed for $\operatorname{diet}(\mathrm{A})$ (Lacking polyunsaturated fatty acids). The difference between the responses of ECOD and EROD activites is probably because the EROD are more specific for polycyclic aromatic hydrocarbon induction (Lech et al., 1982; Fisk et al., 1997 ; Straus et al., 2000).

Ankley and Blazer (1988) and Straus et al. (2000) suggested that their results on differential induction of EROD and ECOD in channel cat fish with Arocolor 1254 could have been related to the presence of polyunsaturated fatty acids (PUFA) in the most inductive diet, which is in agreement with our results . Recently' Ankley et al. (1989) and Kakela et al. (2001) have shown that the relative abundance in $n-3$ series fatty acids (essentially 18:3,20:5 and 22:6) in diet containing medhaden oil, increased basal EROD and. ECOD activities. On the other hand. Ankley and Blazer, (1988) and Kakela et al., (2001) suggested that variation in hepatic activities could be due to vitamin $C$ or vitamin $E$ and PUFAS. Fat deficiency may prevent these changes even in a long term subchronic exposure. The present results indicate an effect of PUFA presence on induction responses. Similar results were found in rats fed with diet rich in nseries fatty acids, where hepatic monooxygenase and GST activities were higher than those obtained with other diets devoid in this series (Century. 1973; Wills 1980: Doi AM el al. 2000). Several hypotheses are proposed to account for variation of hepatic biotransformation activities in relation to diet. Wills (1980) and Wade ef al. (1986) reported that the higher inductions of hepatic biotransformation activity with $C_{22}: 6$ fatty acid diet content could be explained by improvement of catalytic possibilities. i.e with membrane topology and/or fluidity alternations or better catalytic sities as shown in mammals by Ankley et al. (1989) who postulated that fatty acids influence enhanced monooxygenase activity in fishes in a similar way like mammals.

The previous studies showed the relatively weak induction of phase II conjugation enzy'me in fishes (Kirby et al.. 1990. Koss ot al. 
1991 : Flammarian et al. 1998). Phase (I metabolism is a potent detoxyifing system of the carcinogens produced by phase l enzymes.

In O.niloticus, the combination of a low phase II to a high phase I induction. indicates the possibility of a dier related increase of neoplasm potential. Moreover the effect of PUFA on intoxication response in fishes, and as in mammals. monooxyenase and phase II activities were affected by the type of lipids fishes received in diet. Also, a standardization of fishes diet is necessary to reduce variability in organic xenobiotic toxicity. Moreover. such results revealed the necessity of more knowledge about fish biology and nutrition in order to use biotransformation activities in biomonitoring studies. The fatty acid rate in the diet should be taken in account to correlate pollutants level and biotransformation activities in freshwater fish in freshwater environments.

\section{REFERENCES}

Adamsòn, R. H. (1967). Drug metabolism in marine vertehrates. Eederation proc.. 26:1047-1055.

Andersson. T. ; koivusauri, U. and Forlin, S. (1985). Xenobiotic biotransformation in the rainbow trout liver and kidney during starvation. Comp. Biochem. Physiol., 82C: $221-225$.

Ankley, G. T. ; Blazer, V. S. : Reinert, R. E. and Agosin, M. (1986). Effects of Aroclor 1254 on cytochrome P-450 dependent monooxygenase, glutathion. S- transferase and UDP glucuronyl transferase activities in channel catfish liver. Aqu. Toxicol., 9: $91-103$.

Ankley, G. T. and Blazer, V. S. (1988). Effect of diet on PCB induced changes in xenobiotic metabolism in the liver of channe! catfish (Ictalurus punctatus). Can. J. Fish. Aqu. Sci., 45,132. 137.

Ankley, G. T. ; Blazer. V. S. ; Plakas, S. M. and Reinert R. E. (1989). Dietary lipid as a factor modulating xenobiotic metabolism in channel cat fish (Ictalurus Punctatus). Can. J. Fish. Aqut. Sci., 46:1141-1146. 
APHA, (1998). Standard Methods for Examination of Water and Wastewater, American Public Health Association. Washington. DC.

Ariyoshi, T. ; Takabatake, E. and Remmer, H. (1970). Durg metabolism in sethanol induced fatty liver Life Sci., 9:361369.

Arizon, O. K. : Ito, T. ; yamaguchi, M. and Ariyoshi, T. (1982). Induction of zinc metallothionein in the liver of rats by lead. Eisej kagaku. 28:94-98.

AUDW, D. and WURS, R. (2001). A field study on EROD activity and quantitative hepatocytological changes in an immature demersal fish. Environ. Pollut., $115(1): 23-32$.

Boon, J. P. ; Van der Meer. J. ; Allchin, C. R. ; Law, R. J. ; Klungsoyr, J. ; Leonards, P. E. ; Spliid, H. ; Storr-Hansen, E. ; Mckenzie, C. and Wells, D. E. (1997). Concentration - dependent changes of $\mathrm{PCB}$ patterns in fish eating mammals: Structural evidence for induction of cytochrome P-450 Arch. Environ . Contam . Toxicol.. $33(3): 298-311$.

Century, B. (1973). A role of the dietary Lipid in the ability of phenobarbital to stimulate drug detoxification. J. Pharmacol. Exp. Ther., 85: 185- 194.

Coweny. C. B. ; Owen. I. M. ; Adron, J. W. and Middleton, C. (1976). Studies on the nutrition of marine flatfish. The effect of different dietary fatty acid composition of turbot (Scophlalamus maximus). Br. J. Nutr.. 36: 479-486.

De-Marco. G. I. and Mc Coy. G. D. (1985). Involvement of cytochrome $b_{s}$ in the hepatic microsomal metabolism of benzo (a) pyrene. Biochem. Biophy's . Res .Commun.. I28 (2) : 621-627.

De Matieis. F. (1988). Toxicological aspects of liver heme biosynthesis. Seminars in Hematology. $54: 321-329$. 
Doi, A. M. : Lou, Z. : Holmes, E. ; Li, C. ; Venugopal, C. S. : James, M. O. and kleinow, K. M. (2000). Effect of micelle.fatty acid composition and 3,4.3,4 tetrachlorobiphenyl exposure on intestinal (14C) bioavailability and biotransformation in channel catfish in situ preparations. Toxicol . Sci.. 55 (1): 85 -96 .

Elisle, T. A. ; Coulombe, J. L. : Williams, J. L. : Shelton, D. W. and Nixon, J. E. (1983). Time and dose - dependent effects of cyclopropenoid fatty acids on the hepatic microsomal mixed function oxidase sytem of rainbow trout. Aquąic. Toxicol.. 4: $139-151$.

Elisle, T. A. ; Nixon, J. E. ; Pawlowski, N. E. and Sinnhuber. R. O. (1978). Effects of dietary cyclopropene fatty acids on the mixed function Oxidase system of the rainbow trout. J. Environ. Pathol. Toxicol., 1: $773-778$.

Ewald, G. (1999). Ecotoxicological aspects of chlorinated fatty acids. Aquat. Ecosyst. Health. Manage. (2), 1: $71-80$.

Fisk, A. T. : Yarechewski, A. 1. ; Metner, D. A. ; Evans, R. E. : Lockhart, W. l. and Muir, D. C. (1997). Accumulation. depuration and hepatic mixed function oxidase enzyme induction in Juvenile rainbow trout and lake white fish exposed to 2.3.7,8 - tetrachlorodibenzeno-p -dioxin . Aquat Toxicol .. $37(2-3): 201-220$.

Flammarian, P. ; Migeon. U. B. : Urios. S. ; Moefin. P. and Garric. $J .(1998)$. Effect of methidathion on the cytochrome P-450 in the cyprinid fish gudgeon (Gobio gobio) . Aqu . Toxicol.. $+2(2): 93-102$.

Flock. I. : Less. M. and Sloane - Stanley. G. M. (1957). A simple method for the isolation and purification of total lipids from animal tissues. J. Biol. Chem.. 226: 1-12.

Frei. I. (1970). Multiplicity and specificity of UDPglucuronyltransferase. Enzym. Biol. Clinic.. 1/: $385-401$. 
Fuji. M. : Nakayama. H. and Yone. Y. (1976). Effect of $n_{-3}$ fatty acid on growth. feed efficiency and fatty acid composition of red sea bream (Chrysophrys major). Rep. Fish. Res. Lab. Kyushu Univ.. 3: 65-86.

Gadabui, B. K. M. and Goksoyr. A. (1996). Biomarker studies in Tilapia (Oreochromis niloticus) caged in. and in mudfish (Clarias anguillans) exposed to sediment from a polluted river in Ghana. West Africa Bibliographic citation:Pollutant Responses in marine organisms. Hinton. D.E (ed.) 275pp.

Garcia. L. M. ; Porte. C. and Albaiges, J. (2000). Organochlorinated pollutants and xenobiotic metabolized. enzymes in $W$. Mediterranean mesopelagic fish. Mar. Pollut . Bull., $40(9)$ : $764-768$.

Gregus, Z. ; Watkin, J. B. ; Thompsont, T. N. ; Harvey, M. J. ; Rozmank, K. and Klaasen, C. D. (1983). Hepatic phase I and phase II biotrans formation in quail and trout : Comparison to other speçies commonly used in toxicity testing. Toxicol . Appl. Pharmacol., 67: 430-441.

Haugen, D. A. ; Vander Hoeven, T. A. and Coon, M. J. (1975). Purified liver microsomal cytochrome P-450 speration and characterization of multiple forms. J. Biol. Chem., 250:3567 -3570 .

Hebig, W. A. ; Pabst, M. J. and Jacoby, W. B. (1974). Gutathione $S$ - transferase . A first enzymatic step in mercapturic acid formation.J. Biol. Chem., 294: $7130-7139$.

Jimenez, B. D. and Burtis, L. S. (1989). Influence of environmental variables on the hepatic mixed function oxidase system in bluegill sunfish, Lepomis machrochirus. Comp. Biochem. Physiol., 93(C) : 11-21.

Jimenez, B. D. ; Burits, L. S. ; Ezell, G. H. ; Egan, B. Z. ; Lee, N. E. ; Beauchamp, J. J. and Mac Carthy, J. F. (1988). The mixed function oxidase system of Bluegill, Lepomis macrochirus : Correlation of activities in experimental and wild fish. Environ. Toxicol. Chem., 4: 703-710. 
Jimenez, B. D. ; Cirmo. C. P. and Mac Carthy, J. F. ( 1987). Effects of feeding and temperature on up-take. elimination and metabolism of benzo(a) pyrene in bluegill sunfish. Aquat. Toxicol., $10(1): 41-58$.

Kakela, R. ; Kinnunen, S. ; Kakela. A. ; Hyvarinen, H. and Asikainen. J. (2001). Fatty acid, lipids and cytochrome P-450 monooxygenase in hepatic microsomes of minks fed fish based diets and exposed to Aroclor 1242. Toxicol. Envron. Health., $64(5): 427-446$.

Kirby, G. M. ; Stalker, M. ; Metcalfe, C. ; Kocal, T. ; Fergusson, H. and Hayes. M. A. (1990). Expression of immuno reactive glutathione $-S$ - transferase in hepatic neoplasms induced by aflatoxin $\mathrm{B}_{1}$ or 1.2-dimethylbenzathracene in rainbow trout. Carcinogenesis, 11:2255-2257.

Koltz, A. V. ; Stegeman, J. J. and Walsh, C. (1984). An alternative 7 - ethoxyresorufin -O- deethylasc : A continuous visible spectro- photometric method for measurement of cytochrome P-450 monoxygenase activity. Anal . Biochem.. I $10: 138-145$.

Koss, G. ; Losekam, M. ; Schuler. E. and Schreiber, I. (1991). The hepatic glutathione content and glutathione -S- transferase activity in the Pike (Esox lucius) and rat. Comp. Biochem . physiol., $99 B(2)$ : 257- 258.

Lech. J. I.: Vodicnick. M. J. and Elcombe. C. R. (1982). Induction of monooxygenase activity in fish. In Aquatic Toxicology ( Edited by Weber L.J.) PP. 107 - 148. Raven Press. New York.

Lemaire. P. (1990). Characterization and biotransformation enzyme induction in a marine fish. sea bass (Dicentrachus labrax). $193 \mathrm{PP} . . \mathrm{Ph}$. D. Thesis . University of Paris . France. 
Lemaire. P. : Mathieu. A. : Carriere. S. : Drai . P. Giudicelli. J. and Lafauire. M. (1990a). The uptake metabolism and biological half life of benzo (a) pyrene in different tissuse of sea bass. (Dicentrachas labrax). Ectox. Envireon. Saf.. 20: 223 233.

Lemaire. P. : Drai. P. ; Mathieu. A. : Lemaire. S: ; Carriere. S. : Giudicelli, J. and Lafaurie. M. (1991 b).Changes with different diets plasma enzyme (GOT.GPT.LDH.ALP) and plasma lipid (cholesterol. triglycerides) of sea bass (Dicentrarchus Labrax). Aquacult.. 93: 63-75.

Lowry, O. H. ; Rosebrough, N. J. ; Farr, A. L. and Randall, R. J. (1951). Protein measurement with the Folin phenol reagent. J. Biol. Chem.. 193: 265- 275.

Masters, B. S. S. ; Williams, C. H. and Kamin, H. (1967). The preparation and properties of microsomal TPNHcytochrome $C$ reductase from pig liver.In Methods in Enzymology (Edited by Fleischer, S. and Packer L.), Vol. 10, PP. $565-673$.

Mosconi, B. N. ; (1987). Hepatic disturbances induced by an artificial feed in the sea bass (Dicentrachus labrax) during the first year of life. Aquacult., 67: 93-99.

Nava, M..E. and Engelhardt, F. R. (1982). Induction of mixed function oxidases by petroleum in the american eel Anguilla rostuata. Arch. Environ. Contam. Toxicol., 11: $141-145$.

Owen, J. M. ; Adron, J. W. ; Middleton, C. and Cowey, C. B. (1975). Elongation and desaturation of dietary fatty acids in turbot, Scophthalmus maximus and rainbow trout. Rich. Lipids, 10:528 - 531 .

Payne, J. F. ; Rahimtula, A. D. and Porter, E. L. (1987). Review and perspective on the use of mixed function oxygenase enzymes in biological monitoring. Comp. Biochem. Physiol., 86C: $233-245$. 
Ryan, D. ; Luay, H. ; West, S. and Levin, W. (1975). Multiple forms of cytochrome P-450 in Phenobarbital and 3methylcholanthrene treated rats. J. Biol. Chem.. 250:2157 $-2163$.

Sarasquete, C. and Segner, H. (2000). Cytochrome P-450 IA in teleostean fishes. A review of immunohistochemical stuies. Sci. Total Environ.. 247 (2-3) : $313-320$.

Sokal, R. R. and Rohif, F. J. (1981). In: Biometry. The Principles and Practice of. Stastistics in Biological Reseash (Edited by Freeman W.H.) 859 PP.San Francisco.

Stegeman. J. J. ; Kloepper, P. J. and Samms, T. (1987). Cytochrome $\mathrm{P}-450$ isoenzymes and monoxygenase activity in aquatic animals. Environ Toxicol. 77(2-3) : $201-220$.

Stegman, J. J. ; Wood, B. R. ; Singh, H. ;.Oleksiak, M. F. and Celander, M. (1997). Cytochrome P-450 in tropical fishes: Catalytic activities, expression of multiple CYP proteins and high levels of microsomal P-450 in liver of fishes from Bermuda. Comp. Biochem. Physiol., 116 (1):61-75.

Storr-Harisen, E. ; Spliid, H. and Boon. J. P. (1995). Patterns of chlorinated biphenyl congeners in harbor seals (Phoca vitulina) and in their food: Statisical analysis. Arch. Environ. Contam. Toxicol.. $28(1): 48-54$.

Stott. W. T. and Sinnhuber. R. O. (1978). Dietary Protein levels and aflatoxin Bl metabolism in rainbow trout (Salmon gairdneri). J. Environ. Pathol. Toxicol.. 2: $379-388$.

Straus. D. L. ; Schlenk. D. and Chambers. J. E. (2000). Hepatic microsomal desulfuration and dearylation of chlorpyrifos and parathion in fingerling channel cat fish: Lack of effect from Aroclor 1254. Aquatic Toxicol .. 50 (1-2): $141-151$.

Tinoco. J. : (1982). Dietary requirements and functions of a linolenic acid in animals. Prog Lipid Res.. 2]: 1-45. 
Uilrich. V. and Weber. P. (1972). The O-dealkylation of 7-ethoxy coumarin by liver microsomes A direct fluorometric test Hoppe Seyler's Physiol. Chem.. 353:1171-1177.

Wade, A. E. ; White. R. A. ; Walton. L. C. and Bellows. J. T. (1985). Dietary fat - a requirement for induction of mixed function oxidase activities in starved refed rats. Biochem. Pharmacol. $3+: 3747-3754$.

Wade, S. R. : Bellow. M. I. and Dharwadkar. S. (1986). Influence of dietary menhaden oil on the enzymes metabolizing drugs and carcinogens. Durg. Nutrient. Interact. . $f$ : 339-347.

Wills, E. D. (1980). The role of polyunsaturated fatty acid composition of the endoplasmic reticulum in the regulation of the rate of oxidative drug and carcinogen metabolism. In Microśomes Drug Oxidations and chemical Carcinogens (Edited by Coon. M. J. et al.,) 1:543-548. Academic Press. NY.

Wolf, C. R. (1986). Cytochrome P-450 :Polymorphic multigene families involved in carcinogen activation. Trends. Genet., $2: 209-214$.

Wong, C. K. ; Yeung, H. y. ; Woo, P. S. and Wong, M. H. (2001). Specific expression of cytochromal $\mathrm{P}-450 \mathrm{IA}_{1}$ gene in gill. intestine and liver of tilapia exposed to coastal sediments. Aquat. Toxicol., $54(1-2)$ : 64-80.

Yuan, Z. ; Wirgin, M. ; Courtenay, S. ; Ikonomou, M. and Wirgin. I. (2001). Is hepatic cytochrome P-450 I $A_{1}$ expression predictive of hepatic burdens of dioxins, furans and PCBs in Atlantic tomcod from the Hudson River estuary? Aquatic. Toxicol. $54(3-4): 217-230$. 
IN THE O. NILOTICUS EXPOSED TO QUINTOZENE

Table (1): Level of different components in commercial diets $A$ and $B$ percent of total diet

\begin{tabular}{|l|l|l|}
\hline Component & Diet A & Diet B \\
\hline Total protein & $45 \%$ & $45 \%$ \\
\hline Cereal & $20 \%$ & $20 \%$ \\
\hline Total fat & $12 \%$ & $12 \%$ \\
\hline $\begin{array}{l}\text { Fish liver oil } \\
(\% \text { of total fat) }\end{array}$ & $0 \%$ & $11 \%$ \\
\hline
\end{tabular}

Table (2): Induction factors (relative to control) of liver microsomal biotransformation enzymes in $O$. niloticus fed with diet A or B.

\begin{tabular}{|l|l|l|}
\hline $\begin{array}{l}\text { Liver microsomal enzymes } \\
\cdot\end{array}$ & Diet A & Diet B \\
\hline Cytochrome P-450 & 1.0 & 1.44 \\
\hline Cytochrome $b_{5}$ & 1.48 & 2.88 \\
\hline NADPH cyiochrome- c-reductase & 0.9 & 1.04 \\
\hline UDPGT & 1.64 & 4.68 \\
\hline GST & 0.75 & 0.57 \\
\hline EROD & 1.90 & 2.80 \\
\hline ECOD & 4.42 & 5.11 \\
\hline
\end{tabular}



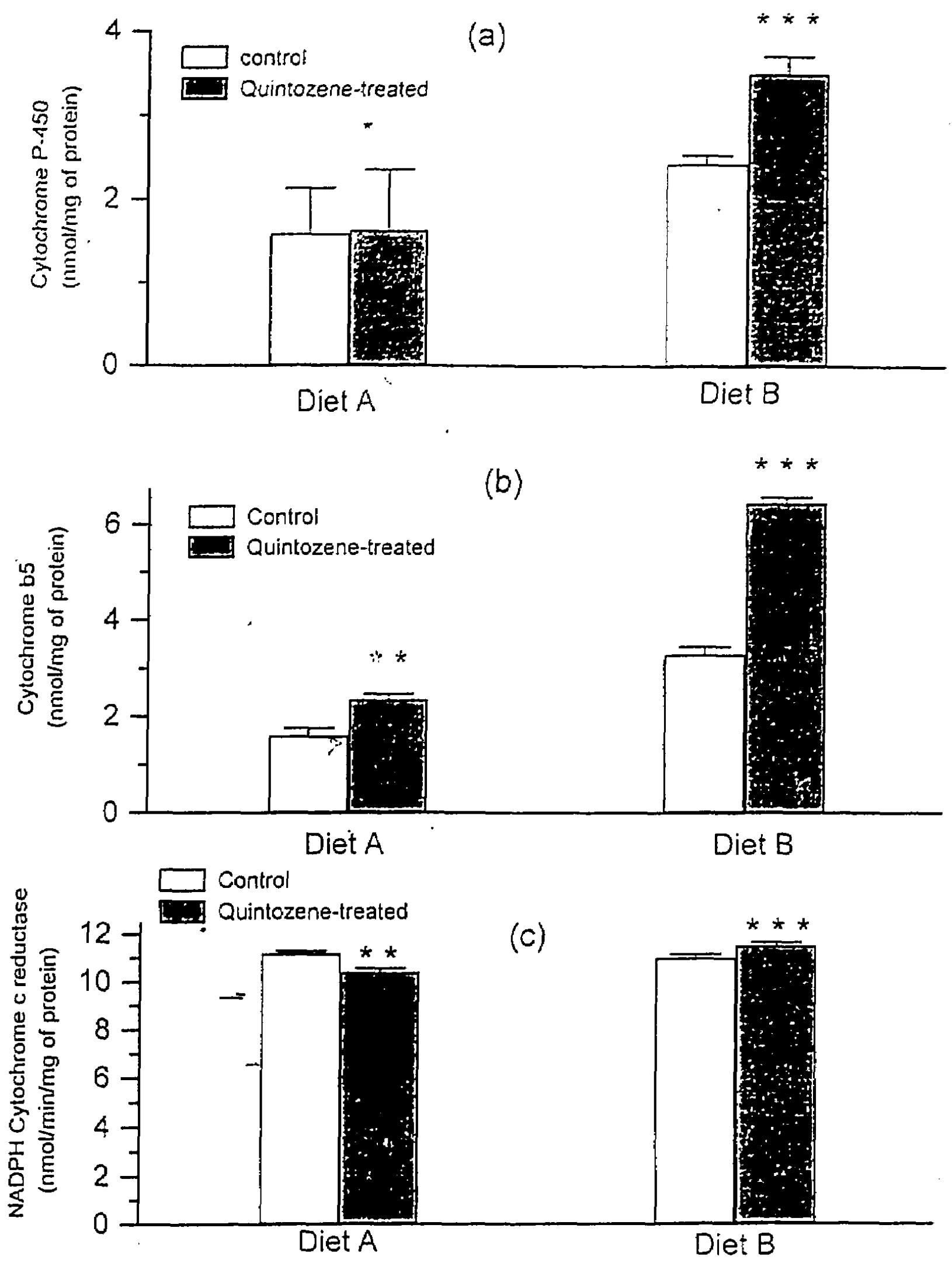

Fig. (1): Effect of diets $A$ and $B$ on the induction of liver microsomal (a) Cytochrome P-450, (b) Cytochrome b5 content and (c) NADPH cytochrome $C$ reductase after quintozene treatment $(30 \mathrm{mg} / \mathrm{kg}$ body weight) in O. niloticus at $48 \mathrm{hrs}$. Mean $+S . D .(n=5)$. 

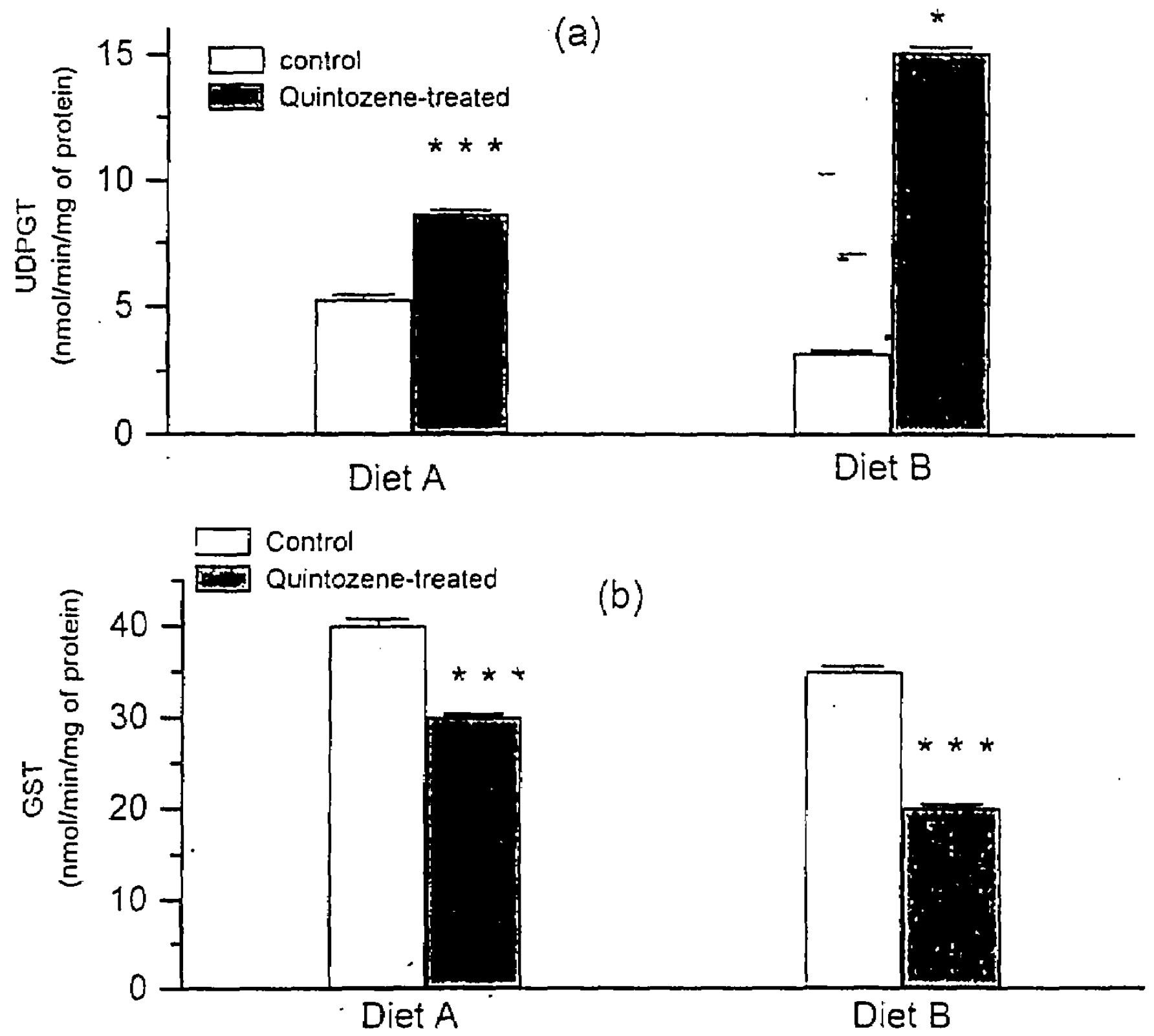

Fig. (2): Effect of diets $A$ and $B$ on the inductionof liver (a)microsomal UDPGT and (b) Cytosolic GST activities after quintozene treatment ( $30 \mathrm{mg} / \mathrm{kg}$ body weight) in O. niloticus at $48 \mathrm{hrs}$. Mean + S.D. $(n=5)$.

PP>0.05 = non significance. $\quad * P<0.05=$ significance

$\cdots P<0.001$ =highly significance 

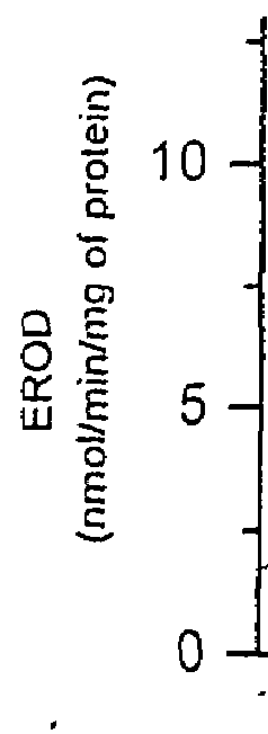

$\square$ control

(a)

Quintozene-treated

* 